УДК 159.99

\section{Алла БОРИСЮК}

ВДНЗУкраїни «Буковинський державний

медичний університет»,

Чернівці (Україна),

borysiuk.alla@bsmu.edu.ua
ПСИХОЛОГІЧНІ ОСОБЛИВОСТІ ПРОФЕСІЙНОЇ

ДІЯЛЬНОСТІ ЛІКАРЯ
PSYCHOLOGICAL FEATURES OF

PROFESSIONAL ACTIVITY OF THE

DOCTOR
Ключевые слова: врач, профессиональная деятельность, больной, профессиональное сознание
Борисюк Алла. Психологические особенности профессиональной деятельности врача.

Взаимное влияние психики и соматики позволяют говорить о целостном подходе к пациенту. Психологические знания являются инструментом для терапевтической помощи и профилактики болезней. Квалифицированная помощь больным в процессе лечения может быть оказана при комплексном взаимодействии медицинского, психологического и социального факторов.
Постановка проблеми. Сучасна система охорони здоров'я в Україні модернізується відповідно до вимог суспільства. Спостерігається зміна глобальної медичної парадигми з патоцентричної на саноцентричну, перехід від медицини-патології до медицини-санології, від нозологічного підходу до особистісного. Зростаюче розуміння психологічних і соціальних аспектів більшості соматичних розладів актуалізує визначення основних моделей взаємодії лікаря і пацієнта, що сприяють ефективній клінічній, психотерапевтичній, соціальній допомозі.

Аналіз особливостей сучасних медичних peaлій все більше переконує викладачів вищих навчальних закладів і лікарів-практиків у тому, що емоційним порушенням у клініці внутрішніх хвороб необхідно приділяти значно більшу увагу, ніж це робилося дотепер. Актуальною потребою сьогодення $\epsilon$ формування в студентівмедиків мистецтва індивідуального підходу до особистості хворого, аналізу й врахування його внутрішньої картини хвороби, психічного стану, емоцій та когніцій, що пов'язані із захворюванням.

Аналіз останніх досліджень і публікацій. На проблемі єдності душі й тіла акцентували увагу відомі мислителі ще в XVII столітті. Р. Декарт, один 3 видатних представників вчення про психофізичний дуалізм, обгрунтував складну теорію взаємодії між тілесним світом і душею. Б. Спіноза в своїй антропології зауважував про те, що все, що відбувається з тілом, має свою відповідність у душі, оскільки душа є ідеєю тіла. Г. В. Лейбніц на місце психофізичної взаємодії поставив спочатку стабілізовану гармонію: між само- стійними процесами тіла й душі існує узгодження ${ }^{1}$.

Серед клініцистів, що писали про взаємозв'язок психічного й соматичного, можна назвати М. О. Аствацатурова, В. А. Гіляровського, Я. П. Фрумкіна, Л. Л. Рохліна, К. А. Скворцова, А. М. Югова та ін. Зокрема, М.О. Аствацатуров підкреслював «специфічність» емоційних станів при враженні внутрішніх органів, вказуючи, що для захворювань серця характерна емоція страху; для захворювань печінки - роздратованість, для захворювань шлунку - апатія.

Значна увага проблемі взаємозв'язку психічного і соматичного приділяється і в наш час. Пацієнт для лікаря не лише об'єкт діагностики і терапії, але й суб'єкт зі складним психологічним світом, який індивідуально реагує на хворобу та умови мікросоціального середовища. Розвиток та поглиблення досліджень психологічного аспекту захворювань дозволяють сприймати хворого не як нозологічну одиницю, а як неповторну індивідуальність.

На значенні психологічного аспекту діяльності лікаря акцентується увага в багатьох працях сучасних дослідників, зокрема М. Аряєва, I. С. Вітенка, В. Т. Волкова, В. Запорожан, Н. М. Манухіної, Б. Любан-Плоцци, В. Пельдингера, С. Д. Соколової, А. К. Стреліс, Ф. Крегера, К. Ледерах-Гофманна та ін.

Існує низка наукових праць, присвячених проблемам медичної освіти в цілому та професійного розвитку лікаря (М. В. Банчук, О. М. Біловол, І. С. Вітенко,Б. Б. Вознесенський, Ю. В. Вороненко, Н. В. Яковлєва, Б. А. Якубов). Дослідження, в яких висвітлюються психологіч- 
ні аспекти допомоги психосоматичним і соматичним хворим (I. С. Вітенко, Л. М. Лежепекова, М. Є. Литвак, Б. Любан-Плоцца, Н. Пезешкіан, А. А. Шутценбергер, І. Ялом), свідчать про специфіку підготовки медичних працівників та своєрідність цього процесу.

I. C. Вітенко наголошує на необхідності посилення психологічного аспекту підготовки лікарів. Як зазначає науковець, аналіз результатів досліджень свідчить, що 65,6 \% листів, які надходять щорічно до Головного лікувальнопрофілактичного управління Міністерства охорони здоров'я України, складають скарги на порушення медичними кадрами етикодеонтологічних та психологічних принципів у процесі надання допомоги та під час спілкування 3 хворими. При цьому пацієнти звертають у листах увагу на байдужість, нестриманість i навіть грубість медичних працівників. Відзначається також, що в лікарів і медичних сестер відсутні елементарні навички встановлення психологічного контакту, через що хворі не могли або не хотіли (при відсутності уваги до них) розкривати своє суб' єктивне ставлення до захворювання.

Оскільки названі явища мають невипадковий характер і негативно впливають на процес діагностики й лікування пацієнтів, виникає необхідність 3'ясувати причини їх виникнення, знайти шляхи подолання.

Проведене I. С. Вітенком вивчення практичної діяльності медичних працівників, опитування і спостереження за їх діяльністю показали, що вказані недоліки в роботі медичного персоналу викликані: а) відсутністю знань 3 психологічних дисциплін $(85,9 \%)$; б) негативним ставленням до професійної діяльності, або відсутністю інтересу до неї (56,3%); в) проявом негативних характерологічних якостей особистості лікаря $(65,4 \%) ;$ г) пасивністю, пов'язаною з відсутністю внутрішньої позитивної мотивації діяльності $(44,7 \%)$; д) недостатнім розумінням сутності впливу психічних станів на виникнення та розвиток соматичних захворювань (51,5 \%) [2].

I. C. Вітенко вивчав думку пацієнтів щодо найбільш важливих професійних якостей лікаря, які забезпечують успішність його діяльності, а також негативних, що заважають налагодженню оптимальної психологічної взаємодії медичного працівника 3 хворими. Результати наведені у таблиці.

Проведене I. C. Вітенком опитування хворих показало, що пацієнти найбільше цінують такі якості лікаря, як пунктуальність (100\% опитуваних), охайність (100\% опитуваних), уважність (100\% опитуваних), здатність до співпереживання (96\% опитуваних), професійні навички, професійний рівень (92,5\% опитуваних). Негативними особистісними рисами лікаря й такими, що заважають довіряти медичному працівникові

пацієнти вважають прояв неуважності з боку лікаря (100\% опитуваних), грубості (92,5\% опи-
Позитивні й негативні якості лікаря

Таблиця 1

\begin{tabular}{|l|l|l|l|l|l|}
\hline $\begin{array}{c}\text { № } \\
\text { I/ } \\
\text { II }\end{array}$ & $\begin{array}{c}\text { Позитивні } \\
\text { якості }\end{array}$ & $\begin{array}{c}\text { Кіль- } \\
\text { кість } \\
\text { опиту- } \\
\text { ваних } \\
\text { (\%) }\end{array}$ & $\begin{array}{c}\text { № } \\
\text { I } \\
/\end{array}$ & $\begin{array}{c}\text { Негатив- } \\
\text { ні } \\
\text { якості }\end{array}$ & $\begin{array}{c}\text { Кіль- } \\
\text { кість } \\
\text { опиту- } \\
\text { ваних } \\
\text { (\%) }\end{array}$ \\
\hline 1. & $\begin{array}{l}\text { Пунктуаль- } \\
\text { ність }\end{array}$ & 100 & 1. & $\begin{array}{l}\text { Неуваж- } \\
\text { ність, } \\
\text { черст- } \\
\text { вість }\end{array}$ & 100 \\
\hline 2. & Охайність & 100 & 2. & $\begin{array}{l}\text { Зарозумі- } \\
\text { лість }\end{array}$ & 94,0 \\
\hline 3. & Уважність & 100 & 3. & Грубість & 92,5 \\
\hline 4. & $\begin{array}{l}\text { Емпатій- } \\
\text { ність }\end{array}$ & 96,0 & 4. & $\begin{array}{l}\text { Неохай- } \\
\text { ність }\end{array}$ & 77,5 \\
\hline 5. & $\begin{array}{l}\text { Професійні } \\
\text { навички }\end{array}$ & 92,5 & & & \\
\hline 6. & $\begin{array}{l}\text { Висока про- } \\
\text { фесійна } \\
\text { кваліфікація }\end{array}$ & 92,5 & & & \\
\hline
\end{tabular}

туваних), зарозумілості (94\% опитуваних), неохайності (77,5\% опитуваних $)^{2}$.

Відомо, що в умовах соціально-політичної та економічної нестабільності окремі члени суспільства інстинктивно обирають найбільш соціально-прийнятливий метод захисту - соматизацію. Адже захворіти «більш природно», ніж визнати (перед собою та іншими) свою некомпетентність. Як зазначають науковці С. Д.Соколова та Н. М. Манухіна, для чоловіка, батька, при тривалій втраті роботи або недостатній заробітній платні, щоб забезпечити сім'ю, захворювання стає єдиним виправдовуючим засобом перед собою та навколишніми. Для дружини, яка протягом багатьох років не працювала, захворювання - це можливість зберегти свій статус домогосподарки тоді, коли чоловік перестає забезпечувати сім'ю3.

Б. Любан-Плоцца та співавтори звертають увагу на те, що ефективність взаємодії лікаря i пацієнта залежить від уміння лікаря встановлювати контакт 3 хворим, у процесі якого пацієнт переконується в можливості використання власних внутрішніх резервів для успішної боротьби 3 хворобою; від здатності створювати терапевтичний клімат, проявляючи щирість, встановлюючи атмосферу взаємної довіри, враховуючи очікування пацієнта від процесу діагностики, лікування, профілактики й реабілітації. ${ }^{4}$

Б. Любан-Плоцца підкреслює, що лише здатність лікаря інтегрувати у своїй роботі три аспекти - біомедичний, психотерапевтичний та соціальнотерапевтичний, робить його справжнім лікарем. Лише за такої умови пацієнт може бути впевнений, що лікар приділить достатньо уваги його біологічним, духовним і соціальним проблемам. Інтеграція цих аспектів «цілісної» медицини здійснюється, на думку автора, двома шляхами: через розширення психосоматичної компетенції лікаря або через тісну співпрацю лікаря $з$ психологом ${ }^{5}$.

Проведений аналіз джерельної бази дає можливість констатувати, що на сьогодні накопиче- 
ний певний досвід підготовки лікарів, педагогів, психологів. Проте залишається невизначеною проблема психологічної підготовки медичного персоналу до роботи 3 пацієнтами, формування їх професійно значущих якостей, відсутні науково обгрунтовані рекомендації щодо ефективного здійснення означеного процесу.

Формулювання цілей та виклад основного матеріалу. У наш час все більш необхідними стають психологічні й психотерапевтичні методи в процесі діагностики й лікування соматичних захворювань. Загальновідоме значення емоційного стресу в формуванні психофізіологічних реакцій організму, що призводять до виникнення серцево-судинних, виразкових та інших психосоматичних захворювань.

У процесі професійної діяльності лікарю надзвичайно важливо вміти виявляти індивідуальні особливості пацієнта й враховувати вплив хвороби на зміну психіки, оскільки одне й те ж захворювання впливає по-різному на внутрішній світ пацієнтів, на міжособистісні стосунки. Встановлення оптимального психологічного контакту вимагає детального вивчення особистісних якостей пацієнта, його індивідуальності. Знання індивідуальних властивостей хворого, особливо його емоційно-вольової сфери, дає змогу лікарю моделювати внутрішній світ пацієнта своїм особистим впливом. У цій моделі поєднуються в єдине ціле різні сторони психологічного плану: загальна і медична культура, симпатія і такт, справжня зацікавленість у психологічному контакті 3 хворим, професійні знання, вміння лікаря тощо.

Професійна свідомість медичного працівника кваліфікується як найважливіша категорія, яка реально відображає суть процесу професійного становлення і розвитку фахівця. Водночас професійна свідомість $є$ психо логічним утворенням, в якому інтегруються професійні цінності, науково-теоретичні знання про себе як про представника професії. Саме вона $\epsilon$ репрезентантом усіх аспектів, рівнів, функцій теоретичного i практичного сегментів професійної діяльності. I, безперечно, сформована професійна свідомість $\epsilon$ основною умовою якісної трудової діяльності та покликана забезпечити цілісність культури фахівця.

У зв'язку з тим, що об'єктом діяльності медика $є$ людина, вимоги до моральних та інтелектуальних якостей фахівця завжди були підвищеними порівняно $з$ іншими професіями. Медична професійна діяльність висуває вимоги, які пов'язані з емоційними перевантаженнями, частими стресовими ситуаціями, дефіцитом часу, необхідністю приймати рішення при обмеженому обсязі інформації і часу, високою частотою та інтенсивністю міжособистісної взаємодії.

За своєю професійною діяльністю фахівецьмедик стикається зі стражданням, болем, смертю. Робота медичного працівника - особливий вид діяльності, який характеризується станом постійної психологічної готовності, емоційного занурення у проблеми хворих, які пов'язані зі станом їх здоров'я ${ }^{6}$.

Професія вимагає від медика дотримання етичних принципів і вимог, оскільки на ньому лежить величезна відповідальність за життя i здоров'я людей. Успішна професійна діяльність медичного працівника визначається такими його особистісними властивостями і особливостями, як співчуття, терпіння і спокій, вміння знайти правильний підхід до кожного хворого, впевненість у власних силах і стійкість в різних ситуаціях у поєднанні з гнучкістю та пластичністю поведінки в нестандартних професійних ситуаціях, що змінюються; високий ступінь стійкості до стресу, до емоційних та інформаційних перевантажень. Медика характеризує наявність розвинених механізмів адаптації і компенсації 3 високою значущістю екзистенційногуманістичних цінностей.

Незважаючи на численні дослідження, присвячені різноманітним аспектам вивчення професійної свідомості лікаря, ця проблема є далекою від остаточного вирішення.

Як зазначалося, сформована професійна свідомість медика забезпечує високу якість його повсякденної професійної діяльності. Вона суб'єктивно проявляється на рівні особистості через усвідомлення нею ступеня розвитку власних професійних здібностей, інтересів, мотивів професійного навчання та фахової діяльності, визнання себе відповідним тим вимогам, які ставить професія, переживання цієї відповідності як сталого почуття задоволення своїм життєвим вибором.

Відомо, що в тих випадках, коли соматизація стає провідним засобом збереження соціального статусу й самооцінки особистості, повне фізичне видужання неможливе. Саме тоді з'являються чисельні скарги на біль, що не відповідають соматичному діагнозу, об'єктивним даним клінічного обстеження та стану пацієнта. В таких випадках на допомогу лікарю повинен прийти психолог, діяльність якого щодо пошуку ресурсів й позитивних аспектів життя пацієнта стає особливо значущою і необхідною, що ще раз підкреслює актуальність підготовки фахівців нового типу - лікарів-психологів.

Все більшого значення набуває робота психолога 3 сімейними проблемами, як в індивідуальній терапії, так і з членами сім'ї пацієнта, а також з сім'єю в цілому. Важливим $є$ не лише вирішення сімейних конфліктів, що призвели до виникнення або загострення захворювання, але й зміна звичних форм поведінки в сім'ї, особливо в період реабілітації пацієнта. Адже якщо для людини захворювання $є$ засобом пристосування до середовища, захистом від психотравмуючої ситуації, то для всієї сім'ї в цілому, як єдиної системи, це спосіб вираження неблагополуччя у взаєминах. Хвора людина при цьому є носієм симптому порушень злагоди в сімейній атмос- 
фері. Саме на включеність захворювання в сімейну систему звертає увагу психолог, коли працює з соматичними пацієнтами.

Не менш важливим аспектом діяльності психолога в процесі роботи з соматичними хворими $\epsilon$ психодіагностика, що є основою вибору методів корекційної роботи. Професійної допомоги психолога часто потребують і лікарі - адже їхня професія є надзвичайно стресогенною і психологічно небезпечною, насамперед - через синдром емоційного вигорання.

Висновки та перспективи дослідження. Взаємовплив психічного й соматичного дозволяє говорити про цілісний підхід до пацієнта. Психологічні знання лікаря є засобом для терапевтичної допомоги та профілактики захворювань. Все більше зростає потреба сучасної медицини в спеціалістах 3 якісною психологічною освітою, яка б відповідала світовим стандартам, у спеціалістах, які будуть компетентні в фундаментальних медико-біологічних, клінічних i психологічних дисциплінах, тобто лікаряхпсихологах.

Мета й професійні завдання лікаря-психолога не є простим поєднанням мети й професійних завдань лікаря та психолога, відповідно й поєднання класичної медичної освіти 3 психологічною не повинне бути суто формальним і не може обмежуватись лише введенням нових навчальних курсів. Передбачається, що це поєднання повинне бути змістовним синтезом, забезпечуючи взаємозв'язок та взаємопроникнення медичних та психологічних знань. Таке вирішення проблеми дозволить сформувати спеціаліста 3 унікальними можливостями, які цілком відповідатимуть сучасним підходам до лікування та реабілітації.

\section{References:}

1. Sokolova E.D., Manuchyna M.N. Psycholohyčeskye aspektы somatyčeskych zabolevanyj // Psycholohyčeskyj žurnal. - 2000. - № 1. - S. 143-144.

2. Vitenko I.S.Psycholohični osnovy pidhotovky medyčnych kadriv. - Ch.: Osnova, 1995. - 158 s.

3. Sokolova E.D., Manuchyna M.N. Psycholohyčeskye aspektы somatyčeskych zabolevanyj // Psycholohyčeskyj žurnal. - 2000. - № 1. - S. 143-144.

4. Ljuban-Plocca B., Zaporožan V., Arjaev N. Terapevtyčeskyj sojuz vrača y pacyenta. - K.: "ADEFUkrayna". - 2001. - 292 s.

${ }^{5}$ Ljuban-Plocca B., Pel'dynher V., Kreher F., Lederach-Chofman K. Psychosomatyčeskye rasstrojstva $\mathrm{V}$ obščej medycynskoj praktyke. - Sankt-Peterburh: Yzdanye Sankt-Peterburhskoho Psychonevrolohyčeskoho ynstytuta ym. V.M.Bechtereva, 2000. - 287 s.

6. Borysjuk A. S. Social'no-psycholohična specyfika profesionalizaciï osobystosti / A. S. Borysjuk // Visnyk Charkivs'koho nacional'noho universytetu imeni V. N. Karazina. - Charkiv, 2007. - Vyp. 38. S. 30-35.
Borysiuk Alla. Psychological Features of Professional Activity of the Doctor. The current health care system in Ukraine is getting upgraded according to the requirements of society. The article describes the process of changing of paradigm of global health from pathocentric to sanocentric that is to say the transition from medicine-pathology to medicine-sanology, from nosological to personal approach. The growing understanding of the psychological and social aspects of most somatic disorders updates the definition of basic models of interaction between doctor and patient, promoting effective clinical, psychological and social assistance.

Analysis of modern medical realities is convincing academics and practitioners that the emotional disturbances in internal diseases clinics should be given much more attention than it has been given to up until now. One of the topical problems today is formation of art of personal approach to each individual patient within the medical students. The upper mentioned approach presupposes teaching students to analise and take into account the internal picture of the patient's disease, the patient's mental state, emotions and kognitions associated with the disease.

The intercommunication of spiritual and corporal psychological allows to speak about integral approach to the patient. Doctor's psychological knowledge is the means of the therapeutic aid and disease prevention. In this respect, combining of the classic medical education with psychological health education should not be only formal and can not be limited to the introduction of new courses. It is assumed that this combination should be meaningful synthesis, providing interconnection and interpenetration of medical and psychological knowledge. This solution will form a specialist with unique features that fully meet modern approaches to treatment and rehabilitation.

Key words: doctor, professional activity , patient professional consciousness.

Борисюк Алла - доктор психологічних наук, професор кафедри психології та соиіології Буковинського державного медччного університету. Коло наукових інтересів: сочіалізація, професійне становлення, професійна ідентичність, професійно значущі якості. Автор понад 70 наукових та навчальнометодичних праць, серед яких монографія, навчальний посібник, рекомендований Міністерством освіти $i$ науки України, три навчальнометодичні посібники, рекомендовані ЦМК з вищої медичної освіти МОЗ України.

Borysiuk Alla - doctor of psychological science, professor at the department of Psychology and Sociology at Bukovinian State Medical University. There are socialization, professional becoming, professional identity, professionaly meaningful features among her scientific interests. Authoring more than 70 scientific and teaching papers, which include: monography, manual authorized by the Ministry for education and science, three teaching manuals authorized by central teaching commitee for higher medical education at Ministry For Health Care of Ukraine

Received: 26-10- 2015

Advance Acces Publischer: December 2015

(C) A. Borysiuk, 2015 